\title{
Type II alveolar epithelial cells and interstitial fibroblasts express connective tissue growth factor in IPF
}

\author{
L-H. Pan*, K. Yamauchi\#, M. Uzuki*, T. Nakanishi", M. Takigawa", H. Inoue ${ }^{\#}$, T. Sawai*
}

Type II alveolar epithelial cells and interstitial fibroblasts express connective tissue growth factor in IPF. L-H. Pan, K. Yamauchi, M. Uzuki, T. Nakanishi, M. Takigawa, H. Inoue, T. Sawai. C ERS Journals Ltd 2001.

ABSTRACT: Connective tissue growth factor (CTGF) is a growth and chemotactic factor for fibroblasts encoded by an immediate early gene that is transcriptionally activated by transforming growth factor- $\beta$. Previous studies have shown that both CTGF messenger ribonuclear acid (mRNA) and protein are expressed in renal fibrosis and bleomycin-induced pulmonary fibrosis in mice. The aim of the present study was to investigate the localization of CTGF protein and its mRNA expression in the fibrotic lung tissue of patients with idiopathic pulmonary fibrosis (IPF).

Using human fibrotic lung tissue obtained from eight autopsy cases and four biopsy cases with IPF, immunohistochemical staining, in situ hybridization, and reverse transcription-polymerase chain reaction (RT-PCR) were performed.

The cellular immunoreactivity for CTGF was markedly increased in the lung tissue of patients with IPF, compared to normal lungs. The immunolocalization of CTGF was confined predominantly to proliferating type II alveolar epithelial cells and activated fibroblasts. In the normal lung, type II alveolar epithelial cells stained for CTGF were sparsely distributed. CTGF mRNA was localized in proliferating type II alveolar epithelial cells and activated fibroblasts in the interstitium of fibrotic lung tissues. RTPCR analysis showed that CTGF mRNA was expressed at a higher level in fibrotic lungs than in normal lungs.

In both an autocrine and a paracrine manner, type II alveolar epithelial cells and activated fibroblasts may play a critical role in pulmonary fibrosis by producing connective tissue growth factor which modulates fibroblast proliferation and extracellular matrix production.

Eur Respir J 2001; 17: 1220-1227.

\begin{abstract}
*First Dept of Pathology and ${ }^{*}$ Third Dept of Internal Medicine, Iwate Medical University School of Medicine, Morioka, Japan, "Dept of Biochemistry and Molecular Dentistry, Okayama University Dental School, Japan.
\end{abstract}

Correspondence: T. Sawai, First Dept of Pathology, Iwate Medical University School of Medicine, Uchimaru 19-1, Morioka 020-8505, Japan. Fax: 81196519246

Keywords: Connective tissue growth factor

idiopathic pulmonary fibrosis immunohistochemistry in situ hybridization transforming growth factor- $\beta$

Received: August 252000

Accepted after revision February 7 2001

Supported by the Ministry of Education, Science and Culture, Japan.
Pulmonary fibrosis proceeds in a cascade fashion beginning with an inflammatory phase, followed by the proliferation of type II alveolar epithelial cells and fibroblasts, and deposition of extracellular matrix (ECM) protein, such as collagen. Previous studies have demonstrated that alveolar macrophages and type II alveolar epithelial cells synthesize various growth factors and cytokines, such as tumour necrosis factor- $\alpha$ (TNF- $\alpha)$, interleukin-1 $\beta$ (IL-1 $\beta)$, platelet derived growth factor (PDGF), and transforming growth factor- $\beta$ (TGF- $\beta$ ), all of which may play important roles in the process of pulmonary fibrosis $[1-8]$. Among these growth factors, TGF- $\beta$ has been thought to be a critical molecule in pulmonary fibrosis [9-14]. Connective tissue growth factor (CTGF), a newly described growth factor which is a cysteine-rich 38-kDa mitogenic peptide, functions as a downstream mediator of the TGF- $\beta$ action in connective tissue cells [15-17]. Previous studies demonstrated that there were CTGF-dependent and CTGF-independent signalling pathways activated by TGF- $\beta$ in fibroblasts $[18-20]$. It is known that CTGF expression is upregulated in bleomycin-induced lung fibrosis, skin fibrosis, renal fibrosis, and other disorders [19, $21-25]$. Recently, Allen et al. [22] reported that the messenger ribonucleic acid (mRNA) level of CTGF in bronchoalveolar lavage cells of patients with idiopathic pulmonary fibrosis (IPF) and sarcoidosis was significantly higher than that in healthy control subjects [22]. However, to date, there is little information on the role of CTGF in interstitial lung diseases, especially in the epithelium and fibroblasts. To extend the findings and investigate whether CTGF is involved in IPF, the immunohistochemical localization of CTGF protein, and CTGF mRNA expression by in situ hybridization in autopsy and biopsy specimens obtained from patients with IPF were studied.

\section{Materials and methods}

\section{Autopsy and biopsy specimens}

Fibrotic lung tissue specimens were obtained from a total of 12 patients (six males, six females, mean age 65.2 yrs, range $36-80 \mathrm{yrs}$ ), including eight cases in 
which autopsy was performed within three post mortem hours at Tohoku University Hospital, and four cases of biopsy by video-assisted thoracic surgery performed at Iwate Medical University Hospital. According to their pathological and clinical features, 12 cases of IPF are compared in table 1. The pathological classification of IPF cases into acute interstitial pneumonia (AIP) $(n=2)$, and usual interstitial pneumonia (UIP) $(\mathrm{n}=10)$ was according to KAtZenstein and Myers [26]. Four normal lung specimens obtained from autopsy and two normal lung specimens from resection of cancer were used as controls. The specimens were fixed in periodatelysine-paraformaldehyde (PLP) for $4-8 \mathrm{~h}$ at $4{ }^{\circ} \mathrm{C}$ and routinely embedded in paraffin wax. Sections, $3 \mu \mathrm{m}$ in thickness, were prepared for immunohistochemical and in situ hybridization studies. For immunohistochemical study, consecutive serial sections were used for all cases. A part of the specimens was snap frozen in liquid nitrogen and stored at $-80^{\circ} \mathrm{C}$.

\section{Cell culture}

Human foetal lung cell line (HFL-1) and human alveolar epithelial cell carcinoma cell line (A549) were purchased from American Tissue Culture Collection (Rockville, MD, USA) and cultured in Roswell Park Memorial Institute (RPMI) 1640 containing $100 \mathrm{U} \cdot \mathrm{mL}^{-1}$ of penicillin, $100 \mu \mathrm{g} \cdot \mathrm{mL}^{-1}$ streptomycin, $2 \mathrm{mM}$ L-glutamine and 10\% foetal calf serum. Cells were used after the second to third passage. Human bronchial epithelial cells were obtained from healthy volunteers by bronchial brushing under bronchoscopy. This was approved by the Ethics Committee of the Iwate Medical University School of Medicine. The cells were cultured in four wells of rat collagen I-coated 12 well tissue culture plates (Iwaki, Funabashi, Japan) in sodium chloride, adenine, glucose, mannitol (SAGM) medium (Clonetics, San Diego, CA, USA) containing $0.5 \mathrm{mg} \cdot \mathrm{mL}^{-1}$ epidermal growth factor $(\mathrm{EGF}), 0.5 \mathrm{mg} \cdot \mathrm{mL}^{-1}$ insulin, $0.1 \mathrm{mg} \cdot \mathrm{mL}^{-1}$ retinoic acid, $0.5 \mathrm{mg} \cdot \mathrm{mL}^{-1}$ epinephrine, $0.5 \mathrm{mg} \cdot \mathrm{mL}^{-1}$ hydrocortisone, $10 \mathrm{mg} \cdot \mathrm{mL}^{-1}$ transfferin, $6.5 \mathrm{mg} \cdot \mathrm{mL}^{-1}$ triiodide thyronine, $50 \mathrm{mg} \cdot \mathrm{mL}^{-1}$ bovine serum albumin-fatty acid free
(BSA-FAF), and $7.5 \mathrm{mg} \cdot \mathrm{mL}^{-1}$ bovine pituitary extract (BPE). These cells were used for ribonucleic acid (RNA) extraction.

\section{Ribonucleic acid extraction}

RNA was extracted from the frozen lung tissues and cultured cells previously described. Healthy lung tissues were obtained from the healthy parts of excised lung tissues of the patients with lung cancer who underwent surgical operation. The healthy lung specimens were evaluated microscopically to be free of cancer cells. Fibrotic lung tissues were obtained from patients with IPF by video-assisted thoracic surgery. Total RNA was isolated by the single-step acid guanidium thiocyanate-phenol-chloroform extraction method as described elsewhere [27].

\section{Antibodies and immunohistochemical staining}

The biotin-streptavidin system was adopted using a Histofine Kit (Nichirei, Tokyo, Japan) for immunohistochemical staining. The sections were deparaffinized and treated with $0.3 \%$ hydrogen peroxide in methanol for 15 min to block endogenous peroxidase activity. The sections were incubated with $10 \%$ normal goat serum for $30 \mathrm{~min}$ at room temperature to block the nonspecific antibody reaction. A specific CTGF polyclonal antibody was used as the primary antibody in the immunohistochemical staining (Okayama University, Japan) [28]. Anti-cytokeratin, CD68, and $\alpha$-smooth muscle actin ( $\alpha$-SMA) (Nichirei, Tokyo, Japan) were also used for distinguishing epithelia, macrophages, and activated fibroblasts, respectively. The antibodies used, working dilution, and sources are listed in table 2. The sections were incubated overnight at $4{ }^{\circ} \mathrm{C}$ with the primary antibodies. 3'3diaminobenzidine (DAB) was used as the chromogenic substrate.

\section{In situ hybridization}

Paraffin sections of the samples fixed in PLP were investigated as described previously, by using a

Table 1. - Contrasting pathological features of idiopathic interstitial pneumonia

\begin{tabular}{|c|c|c|c|c|c|c|c|c|}
\hline \multirow[b]{2}{*}{ Case } & \multirow[b]{2}{*}{ Sex } & \multirow[b]{2}{*}{ Age } & \multirow[b]{2}{*}{$\begin{array}{l}\text { Pathological } \\
\text { classification }\end{array}$} & \multicolumn{5}{|c|}{ Features } \\
\hline & & & & $\begin{array}{l}\text { Hyaline } \\
\text { membranes }\end{array}$ & $\begin{array}{l}\text { Interstitial } \\
\text { inflammation }\end{array}$ & $\begin{array}{l}\text { Type II alveolar } \\
\text { epithelial proliferation }\end{array}$ & $\begin{array}{l}\text { Fibroblast } \\
\text { proliferation }\end{array}$ & $\begin{array}{l}\text { Collagen } \\
\text { fibrosis }\end{array}$ \\
\hline $1^{*}$ & $\mathrm{~F}$ & 36 & AIP & Focal & Scant & Focal & Scant & No \\
\hline $2^{*}$ & $\mathrm{~F}$ & 80 & AIP & Focal & Scant & Marked & Scant & No \\
\hline $3^{*}$ & $\mathrm{~F}$ & 72 & UIP with acute exacerbation & Focal & Scant & Marked & Rare & Patchy \\
\hline $4^{*}$ & $\mathrm{M}$ & 58 & UIP with acute exacerbation & Focal & Focal & Focal & Prominent & Patchy \\
\hline $5^{*}$ & M & 64 & UIP with acute exacerbation & Focal & Focal & Marked & Prominent & Patchy \\
\hline $6^{*}$ & M & 65 & UIP with acute exacerbation & Focal & Scant & Marked & Prominent & Patchy \\
\hline $7^{*}$ & $\mathrm{~F}$ & 74 & UIP with acute exacerbation & Focal & Scant & Marked & Diffuse & Patchy \\
\hline $8^{*}$ & M & 78 & UIP with acute exacerbation & Diffuse & Scant & Focal & Rare & Patchy \\
\hline $9 * *$ & M & 73 & UIP with acute exacerbation & Focal & Scant & Marked & Prominent & Patchy \\
\hline $10 * *$ & $\mathrm{~F}$ & 65 & UIP & No & Focal & Marked & Focal & Patchy \\
\hline $11 * *$ & M & 51 & UIP & No & Focal & Marked & Prominent & Patchy \\
\hline $12 * *$ & $\mathrm{~F}$ & 66 & UIP & No & Scant & Marked & Prominent & Patchy \\
\hline
\end{tabular}

F: female; M: male; AIP: acute interstitial pneumonia; UIP: usual interstitial pneumonia; *: autopsy; **: open biopsy case. 
Table 2. - Source and working dilution of the antibodies

\begin{tabular}{llcc}
\hline Antibodies & Source & Working dilution & Chromogenic substrate \\
\hline Rabbit antihuman CTGF & Okayama University & $1: 500$ & DAB \\
Mouse antihuman CD68 (PGM1) & DAKO Gostrup, Denmark & $1: 100$ & DAB \\
Mouse antihuman cytokeratin & Nichirei Co, Japan & $1: 200$ & DAB \\
Mouse antihuman $\alpha$-SMA & Nichirei Co, Japan & $1: 200$ & DAB \\
\hline
\end{tabular}

CTGF: connective tissue growth factor; $\alpha$-SMA: alpha-smooth muscle actin; DAB: 3'3-diaminobenzidine.

slightly modified nonradioactive in situ hybridization technique with digoxigenin-labelled RNA probes [29, 30]. Briefly, paraffin-embedded tissues were cut into $3-\mu \mathrm{m}$ thin sections, mounted onto silane-coated slides, deparaffinized, and treated with pronase $\left(0.25 \mathrm{mg} \cdot \mathrm{mL}^{-1}\right.$ in $50 \mathrm{mM}$ Tris-hydrochloric acid $(\mathrm{HCl}), \mathrm{pH} 7.6$, containing $5 \mathrm{mM}$ ethylendiaminetetraacetic acid (EDTA)) digestion for $10 \mathrm{~min}$ at room temperature followed by $0.05 \mathrm{~N} \mathrm{HCl}$ for $10 \mathrm{~min}$. The sections were then postfixed with 4\% paraformaldehyde in phosphate buffered saline (PBS) for $15 \mathrm{~min}$ and treated with glycine $\left(2 \mathrm{mg} \cdot \mathrm{mL}^{-1}\right.$ in PBS) twice for $3 \mathrm{~min}$ each. After washing with PBS, the samples were acetylated with a freshly prepared mixture of $0.25 \%$ acetic anhydride in triethanolamine buffer for $10 \mathrm{~min}$.

A 2100-base pair fragment of CTGF complementary deoxyribonucleic acid (cDNA) was subcloned into the EcoRI site of Bluescript phagemid and used to prepare probes. The DNA was linearized by using XbaI to prepare the antisense strand and XhoI for the sense strand. The probes were labelled with digoxigenin-11-UTP by using a digoxigenin (DIG) RNA-labelling kit (Boehringer Mannheim Biochemical, Germany) [16, 28].

The labelled RNA probes $\left(1 \mu \mathrm{g} \cdot \mathrm{mL}^{-1}\right)$, in a mixture containing $50 \%$ formamide, $10 \%$ dextran sulphate, $1 \times$ Denhardt's solution, $500 \mu \mathrm{g} \cdot \mathrm{mL}^{-1}$ transfer ribonucleic acid (tRNA), $80 \mu \mathrm{g} \cdot \mathrm{mL}^{-1}$ sermon sperm DNA, $0.3 \mathrm{M}$ sodium chloride $(\mathrm{NaCl}), 1 \mathrm{mM}$ EDTA, and $10 \mathrm{mM}$ Tris- $\mathrm{HCl}, \mathrm{pH} 7.0$ were placed on the slides and cover-slipped.

Hybridization was performed in a humidified chamber for $18 \mathrm{~h}$ at $45^{\circ} \mathrm{C}$. For the negative control, sense probes were used. They were then rinsed for $10 \mathrm{~min}$ in $2 \times$ sodium citrate sodium chloride (SSC) twice and in $0.5 \times \mathrm{SSC}$ twice at $45^{\circ} \mathrm{C}$. The digoxigenin-labelled probes were visualized as per the protocol described in the DIG nucleic acid detection kit (Boehringer Mannheim Biochemical, Germany). Methyl green was used as the counter-stain.

Reverse transcription-polymerase chain reaction for connective tissue growth factor messenger ribonucleic acid

The primers were designed from the published sequences from human CTGF cDNA [31], as follows: sense, 5'-TTCCAGAGCAG-CTGCAAGTACCA-3'; antisense, 5'-TTGTCATTGGTAACCCGGGTGGA$3^{\prime}$. As a control, the primers for glyceraldehyde3-phosphate dehydrogenase (GAPDH) mRNA were also designed as follows: sense, 5'-TAAAG GTGGAGTCAAACGGATTTGGT-3'; antisense, 5'-CATGTGGGCCA-TGAGGTCCACCAC-3' [32].
cDNA was generated by reverse transcription $(\mathrm{RT})$ of $0.5 \mu \mathrm{g}$ of aliquots of total RNA in a total volume of $20 \mu \mathrm{L}$ containing $1 \times$ polymerase chain reaction (PCR) buffer $(10 \mathrm{mM}$ Tris- $\mathrm{HCl}, \mathrm{pH} 8.3 ; 50 \mathrm{mM}$ potassium chloride $(\mathrm{KCl}) ; 5 \mathrm{mM}$ magnesium chloride $\left(\mathrm{MgCl}_{2}\right) ; 1 \mathrm{mM}$ of each deoxynucleotide triphosphate (dNTP), $1 \mathrm{U}$ ribonuclease (RNase) inhibitor, and $2.5 \mathrm{U}$ murine leukaemia virus $(\mathrm{MuLV})$ reverse transcriptase) at $42^{\circ} \mathrm{C}$ for $15 \mathrm{~min}$ (PCR reagents were purchased from Perkin Elmer, Applied Biosystems Division, Foster City, CA, USA). Twenty $\mu \mathrm{L}$ of the RT reaction were used for PCR amplification in a total volume of $100 \mu \mathrm{L}$ using $0.5 \mathrm{U}$ Taq-polymerase and primers (20 pmol each).

Amplification was done with 35 cycles, with denaturation at $95^{\circ} \mathrm{C}$ for $15 \mathrm{~s}$, primer annealing and extension at $60^{\circ} \mathrm{C}$ for $30 \mathrm{~s}$, followed by a final extension at $72^{\circ} \mathrm{C}$ for $7 \mathrm{~min}$ using the GeneAmp PCR System 2400 (Perkin Elmer). The cycle number of PCR was selected where the reaction was exponential on the basis of preliminary experiments. The expected fragment from this process should exhibit 329 base pairs. Aliquots of $10 \mu \mathrm{L}$ of PCR reaction mixture were size-fractionated by electrophoresis on 1.5\% agarose gels (NuSieve GTG; FMC BioProducts, Rockland, ME, USA) in TBE-buffer (i.e. $89 \mathrm{mM}$ Tris base, $89 \mathrm{mM}$ boric acid, $2 \mathrm{mM}$ EDTA). PCR products were visualized by staining gels with ethydium bromide.

\section{Results}

Immunostaining for connective tissue growth factor in normal lung tissue

Normal control tissues were characterized by a thin alveolar wall with few intra-alveolar macrophages. Type II alveolar epithelial cells were observed sparsely. Staining for type IV collagen revealed a uniform, smooth linear pattern along the epithelial and capillary basement membranes (data not shown). Immunoreactivity for CTGF was observed sparsely in a few type II alveolar epithelial cells (fig. 1a). In these cells, type II alveolar epithelial cells were identified by cytokeratin immunoreactivity (fig. 1b), whereas macrophages stained positive for CD68 (fig. 1c).

Immunostaining for connective tissue growth factor in the lung tissue of patients with idiopathic pulmonary fibrosis

Morphologically, the changes observed in specimens of fibrotic lung disease (AIP and UIP with acute 

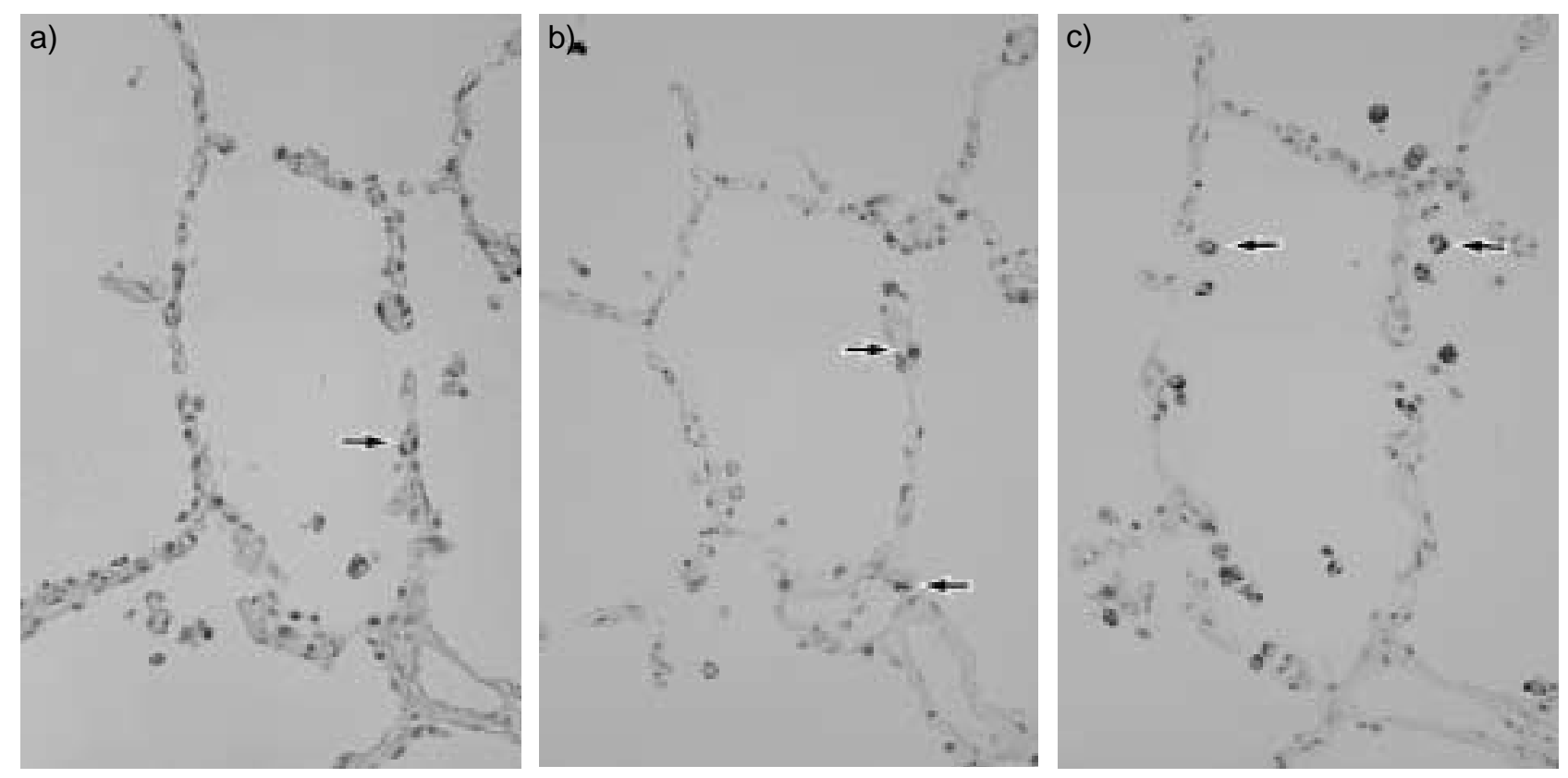

Fig. 1. - Normal lung tissue, immunohistochemical staining (consecutive serial sections): a) Staining for connective tissue growth factor (CTGF) arrow indicates type II epithelial cell which is positive. b) Staining for cytokeratin, arrows indicate type II epithelial cells which are positive c) Staining for CD68, arrows indicate macrophages which are positive.

exacerbation) were focal hyaline membrane formation apposed to the alveolar walls, intra-alveolar accumulation of macrophages and activated fibroblasts (myofibroblasts) infiltrated in the eosinophilic oedematous matrix (fig. 2a). Variable thickening of the alveolar septa with focal discontinuities in the alveolar basal lamina were visualized by immunostaining for type IV collagen (data not shown). Type II alveolar epithelial cells (hypertrophy pneumocytes) were positive for CTGF (fig. 2b, 3a), identified by immunostaining for cytokeratin (fig. 2c, 3b). Most alveolar macrophages were negative for CTGF, identified by immunostaining for CD68 (fig. 2d). Activated fibroblasts containing $\alpha$-SMA in the interstitium were positive for CTGF (fig. 3c). At the foci of old fibrosis in UIP, the normal alveolar architecture was lost and replaced by areas with deposition of collagen fibre, where activated fibroblasts were sparse. Alveolar macrophages and proliferated type II alveolar epithelial cells were sparsely distributed, and they were weakly positive or negative for CTGF (data not shown).

Localization of connective tissue growth factor detected by in situ hybridization

In the present study, four cases were examined by in situ hybridization and a positive purple staining was observed in proliferating type II alveolar epithelia lining the alveolar walls and activated fibroblasts of the interstitium (fig. 4a, 4b). Control sections hybridized with the CTGF sense probe showed no signals (fig. 4c).
Connective tissue growth factor expression analysed by reverse-transcription polymerase chain reaction

CTGF mRNA expression was evaluated by RTPCR in normal lung tissues and in the lung tissues of IPF. In addition, CTGF mRNA expression was also evaluated in HFL-1, A549 and human cultured bronchial epithelial cells (lane 7-9). Weak bands corresponding to CTGF mRNA were observed in normal lung tissue compared to those of IPF (fig. 5, panel A lane 1-6). Conversely, the amount of RTPCR products from GAPDH mRNA in normal lung tissues appeared to be at the same level as in IPF (fig. 5, panel B), suggesting that the CTGF mRNA level in the lung tissue of IPF might be higher than that in the normal lung tissue.

\section{Discussion}

In the present study using fibrotic lung tissues of IPF demonstrated the expression and localization of CTGF mRNA and protein by in situ hybridization and immunohistochemical staining, respectively, in both a large number of proliferating type II alveolar epithelial cells and activated fibroblasts of the interstitium. In addition, CTGF mRNA was detected by RT-PCR in the lung tissue of IPF, HFL-1 cells, A549 and cultured human bronchial epithelial cells.

LASKY et al. [19] reported that there was an increase in CTGF mRNA expression in both human and murine lung fibroblasts stimulated with TGF- $\beta$ in vitro. In addition, they demonstrated that $\mathrm{CTGF}$ mRNA expression was upregulated in bleomycininduced lung fibrosis in mice in vivo. AlLEN et al. [22] 

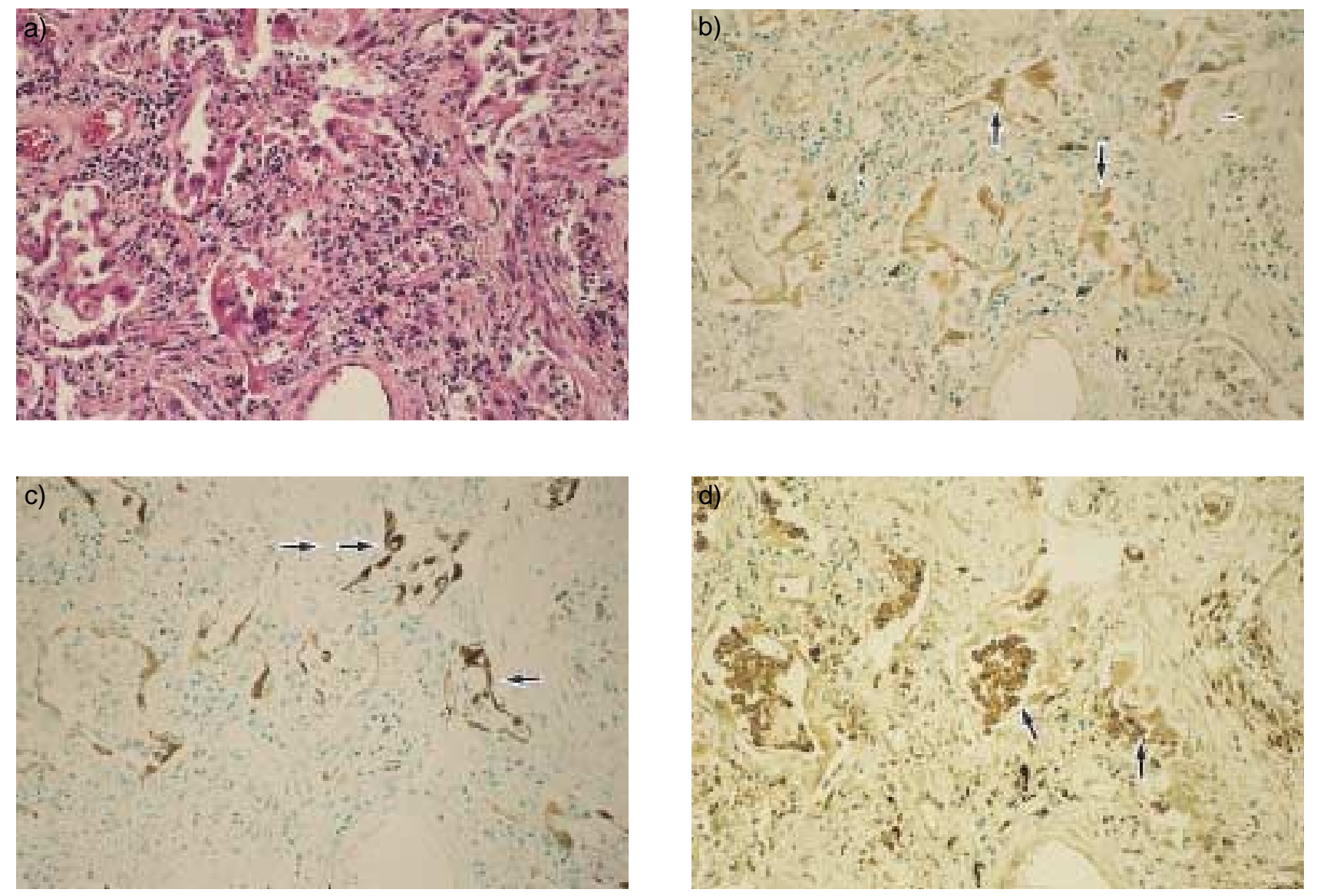

Fig. 2. - Fibrotic lung tissue of IPF. Consecutive serial sections. (a: hematoxylin-eosin staining; bed: immunohistochemical staining). a) Proliferating alveolar macrophages, type II epithelial cells and fibroblasts. b) Staining for connective tissue growth factor (CTGF), arrows indicate proliferating type II epithelial cells which are positive. Small arrows indicate activated fibroblast which is positive. c) Staining for cytokeratin, arrows indicate type II epithelial cells which are positive. d) Staining for CD68, arrows indicate alveolar macrophages which are positive.

used a multiplex competitive RT-PCR to quantify insulin-like growth factor binding protein-related protein 2 (IGFBP-rP2) (CTGF) transcripts in bronchoalveolar lavage cells from healthy subjects and patients with IPF. IGFBP-rP2 messenger RNA expression was enhanced $>10$-fold in patients with IPF. They also suggested that the cellular sources of the elevated level of CTGF mRNA were neutrophils and lymphocytes. The present study could not evaluate this possibility because few such cells were seen. It has been demonstrated that CTGF is secreted by fibroblasts in human organs other than the lung and have a role in stimulating fibroblast cell growth, matrix production, and granulation tissue formation [21, 23-25, 33]. In addition, CTGF mRNA has been shown to be expressed predominantly in visceral and parietal epithelial cells of kidney of patients with renal fibrosis [25]. The present study also demonstrated CTGF mRNA expression in human primary cultured bronchial epithelial cells and alveolar epithelial cell carcinoma cell line A549, suggesting that pulmonary epithelial cells may have the ability to express CTGF. To date, there is little information on the role of CTGF in pulmonary fibrosis, especially in the epithelium. The present results suggest that the expression of CTGF protein and its mRNA in IPF were increased. These data demonstrate that both proliferating type II alveolar epithelial cells and activated fibroblasts may contribute to the pathogenesis of lung fibrosis by producing CTGF.

The present study observed strong expressions of CTGF in proliferating type II alveolar epithelial cells and activated fibroblasts situated in the area of fibrotic interstitium only in the earlier stage of fibrotic changes. In the later stage of fibrotic changes, active fibroblasts are few and lack the expression of CTGF. Therefore, it is speculated that CTGF produced by activated fibroblasts may contribute to active fibrotic process in an early stage of pulmonary fibrosis.

Previous studies have demonstrated that CTGF activation is followed by that of TGF- $\beta$ [16-18]. CTGF may serve as a more specific mediator in processes involving connective tissue formation during wound repair or fibrotic disorders. The present study was not able to investigate CTGF functions as a downstream mediator of TGF- $\beta$ action on connective tissue cells directly. However, in fibrotic lung tissues, TGF- $\beta$ expression was observed in type II epithelial 

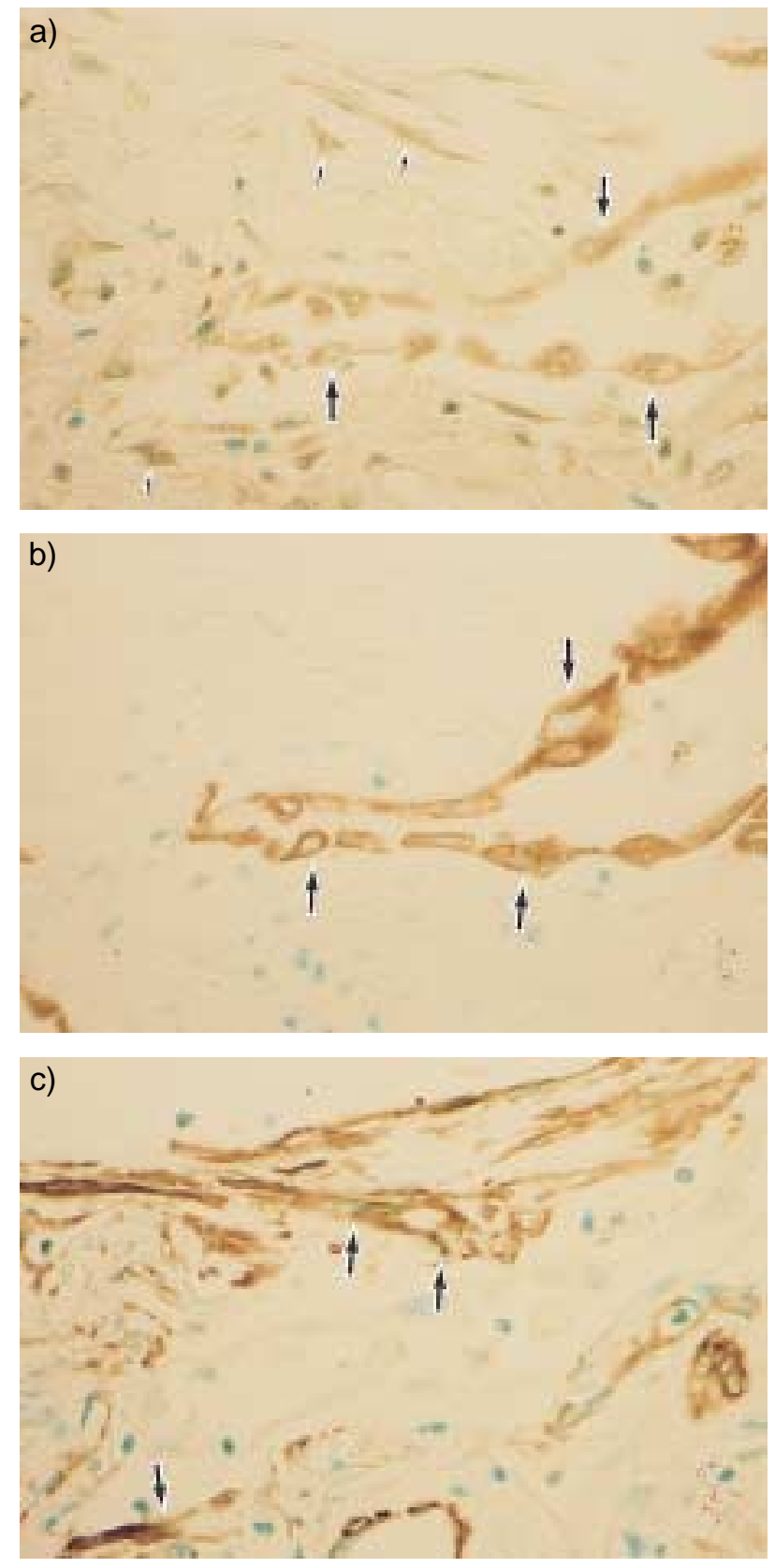

Fig. 3. - Fibrotic lung tissue of idiopathic pulmonary fibrosis. Consecutive serial sections. a) Staining for connective tissue growth factor (CTGF), arrows indicate proliferating type II epithelial cells which are positive. Small arrows indicate activated fibroblast which is positive. b) Staining for cytokeratin, arrows indicate type II epithelial cells which are positive. c) Staining for alpha smooth muscle actin (a-SMA), arrows indicate activated fibroblasts which are positive.

cells, fibroblasts and alveolar macrophages by immunohistochemical staining $[34,35]$. TGF- $\beta$ shared part of the same immunostaining pattern as CTGF without alveolar macrophages. The present authors suggest that CTGF produced mainly by type II epithelial cells and activated fibroblasts, may also be a mediator of TGF- $\beta$ action on fibroblasts in IPF.

The present results indicate that not only activated
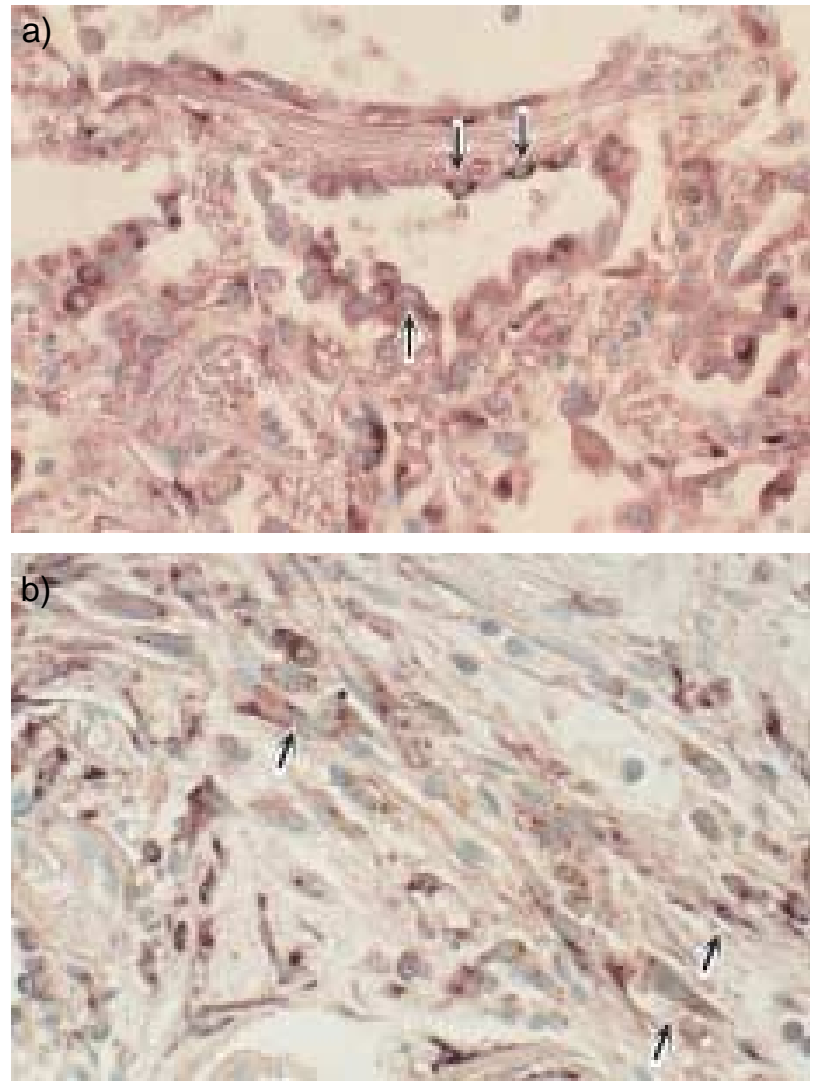

c)

Fig. 4. - Fibrotic lung tissue of idiopathic pulmonary fibrosis. In situ hybridization. Methyl green as counterstain. a) In situ hybridization for connective tissue growth factor (CTGF), arrows indicate type II alveolar epithelial cells which are positive. b) In situ hybridization for CTGF, arrows indicate activated fibroblasts which are positive. c) Control with sense probes, no positive signals are observed.

fibroblasts, but also proliferating type II alveolar epithelial cells, are main sources of connective tissue growth factor in the lungs of fibrotic diseases such as idiopathic pulmonary fibrosis. Via both an autocrine and a paracrine route of cytokine action, connective tissue growth factor produced by type II alveolar epithelial cells and activated fibroblasts may have the potential to stimulate fibroblast proliferation and the production of extracellular matrix involved in pulmonary fibrosis. 
(a)
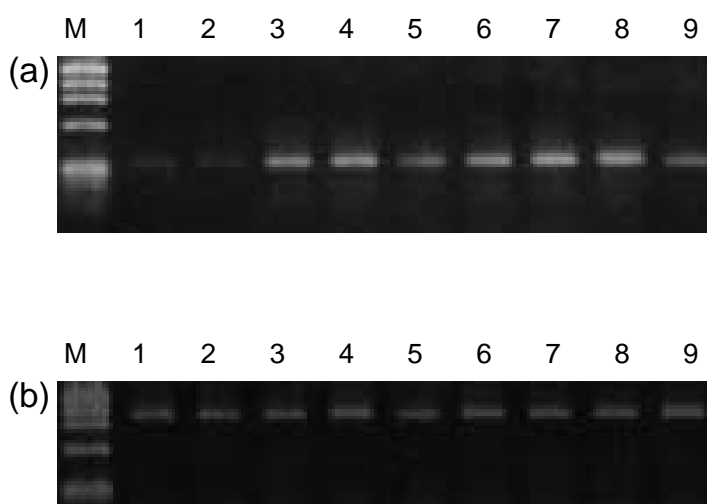

Fig. 5. - Expression of connective tissue growth factor (CTGF) and glyceraldehyde-3-phosphate dehydrogenase (GAPDH) messenger ribonucleic acids (mRNAs) detected by reverse transcription-polymerase chain reaction. Ethidium bromide-stained agarose gel showing panel a) (CTGF) and panel b) (GAPDH) $1-2$ : normal lung tissue; 3-6: Idiopathic pulmonary fibrosis; 7: human foetal lung-1; 8: human primary cultured bronchial epithelial cells; 9: A549. M: molecular markers (phage Hae III fragments). Arrows indicate bands of PCR products of CTGF (329 bp) in panel 9 and GAPDH (983 bp) in panel b.

\section{References}

1. Piguet PF, Ribaux C, Karpuz V, Grau GE, Kapance Y. Expression and localization of tumor necrosis factor- $\alpha$ and its mRNA in idiopathic pulmonary fibrosis. Am J Pathol 1993; 143: 651-655.

2. Pan LH, Ohtani H, Yamauchi K, Nagura H. Coexpression of TNF $\alpha$ and IL-1 $\beta$ in human acute pulmonary fibrotic diseases: An immunohistochemical analysis. Pathol International 1996; 46: $91-99$.

3. Zhang Y, Lee TC, Guillemin B, Yu MC, Rom WN. Enhanced IL-1 beta and tumor necrosis factor-alpha release and messenger RNA expression in macrophages from idiopathic pulmonary fibrosis or after asbestos exposure. J Immunol 1993; 150: 4188-4196.

4. Martinet Y, Rom WN, Grotendorst GR, Martin GR, Crystal RG. Exaggerated spontaneous release of platelet-derived growth factor by alveolar macrophages from patients with idiopathic pulmonary fibrosis. $N$ Engl J Med 1987; 317: 202-209.

5. Antoniades HN, Bravo MA, Avila RE, et al. Plateletderived growth factor in idiopathic pulmonary fibrosis. J Clin Invest 1990; 86: 1055-1064.

6. Khalil N, O'Connor RN, Unruh HW, et al. Increased production and immunohistochemical localization of transforming growth factor-beta in idiopathic pulmonary fibrosis. Am J Respir Cell Mol Biol 1991; 5: $155-$ 162 .

7. Broekelmann TJ, Limper AH, Colby TV, McDonald JA. Transforming growth factor $\beta 1$ is present at sites of extracellular matrix gene expression in human pulmonary fibrosis. Proc Natl Acad Sci USA 1991; 88: $6642-6646$

8. Zhang K, Flanders KC, Phan SH. Cellular localization of transforming growth factor- $\beta$ expression in bleomycin-induced pulmonary fibrosis. Am J Pathol 1995; 147: $352-361$.

9. Elias JA, Freundlich B, Kern JA, Rosenbloom J. Cytokine networks in the regulation of inflammation and fibrosis in the lung. Chest 1990; 97: 1439-1445.
10. Khalil N, Greenberg AH. The role of TGF-beta in pulmonary fibrosis. Ciba Foundation Symposium 1991; 157: $194-211$.

11. Gauldie J, Jordana M, Cox G. Cytokines and pulmonary fibrosis. Thorax 1993; 48: $931-935$.

12. Border WA, Noble NA. Transforming growth factor $\beta$ in tissue fibrosis. $N$ Engl J Med 1994; 331: 12861292.

13. Vailant P, Menard O, Vignaud J-M, Martinet N, Martinet Y. The role of cytokines in human lung fibrosis. Monaldi Arch Chest Dis 1996; 51: 145-152.

14. Zhang K, Phan SH. Cytokines and pulmonary fibrosis. Biological Signals 1996; 5: 232-239.

15. Igarashi A, Okochi H, Bradham DM, Grotendorst GR. Regulation of connective tissue growth factor gene expression in human skin fibroblasts and during wound repair. Mol Biol Cell 1993; 4: 637-645.

16. Nakanishi T, Kimura Y, Tamura T, et al. Cloning of a mRNA preferentially expressed in chondrocytes by differential display-PCR from a human chondrocytic cell line that is identical with connective tissue growth factor (CTGF) mRNA. Biochem Biophys Res Commun 1997; 234: 206-210.

17. Frazier K, Williams S, Kothapalli D, Klapper H, Grotendost GR. Stimulation of fibroblast cell growth, matrix production, and granulation tissue formation by connective tissue growth factor. J Invest Dermatol 1996; 107: $404-411$.

18. Grotendorst GR. Connective tissue growth factor: a mediator of TGF- $\beta$ action on fibroblasts. Cytokine Growth Factor Rev 1997; 8: $171-179$.

19. Lasky JA, Ortiz LA, Tonthat B, et al. Connective tissue growth factor mRNA expression is upregulated in bleomycin-induced lung fibrosis. Am J Physiol 1998; 275: L365 - L371.

20. Kothapalli D, Frazier K, Grotendorst GR. TGF- $\beta$ induces anchorage-independent growth of NRK fibroblasts via the synergistic action of CTGFdependent and CTGF-independent signalling pathways. Cell Growth Differ 1997; 8: 61-68.

21. Igarashi A, Hayashi N, Nashiro K, Takehara K. Differential expression of connective tissue growth factor gene in cutaneous fibrohistiocytic and vascular tumors. J Cutan Pathol 1998; 25: 143-148.

22. Allen JT, Knight RA, Bloor CA, Spiteri MA. Enhanced insulin-like growth factor binding proteinrelated protein 2 (connective tissue growth factor) expression in patients with idiopathic pulmonary fibrosis and pulmonary sarcoidosis. Am J Respir Cell Mol Biol 1999; 21: 693-700.

23. Igarashi A, Nashiro K, Kikuchi K, et al. Connective tissue growth factor gene expression in tissue sections from localized scleroderma, keloid, and other fibrotic skin disorders. J Invest Dermatol 1996; 106: 729-733.

24. Oemar BS, Werner A, Gamier J-M, et al. Human connective tissue growth factor is expressed in advanced atherosclerotic lesion. Circulation 1997; 95: $831-839$.

25. Ito $\mathrm{Y}$, Aten $\mathrm{J}$, Bende $\mathrm{RJ}$, et al. Expression of connective tissue growth factor in human renal fibrosis. Kidney International 1998; 53: 853-861.

26. Katzenstein AL, Myers JL. Idiopathic pulmonary fibrosis: clinical relevance of pathologic classification. Am J Respir Crit Care Med 1998; 157: 1301-1315.

27. Chomczynski P, Sacchi N. Single-step method of RNA isolation by acid guanidinium thiocyanate- 
phenol-chloroform extraction. Anal Biochem 1987; 162: $156-159$.

28. Shimo T, Nakanishi T, Kimura, et al. Inhibition of endogenous expression of connective tissue growth factor by its antisense olignucleotide and antisense RNA suppresses proliferation and migration of vascular endothelial cells. J Biochem 1998; 124: $130-$ 140.

29. Sawai T, Uzuki M, Harris ED Jr, Kurkinnen M, Trelstad RL, Hayashi M. In situ hybridization of stromelysin mRNA in the synovial biopsies from rheumatoid arthritis. Tohoku J Exp Med 1996; 178: $315-330$.

30. Mori T, Kawara S, Shinozaki M, et al. Role and interaction of connective tissue growth factor with transforming growth factor- $\beta$ in persistent fibrosis: a mouse fibrosis model. J Cell Physiol 1999; 181: $153-$ 159.

31. Bradham DM, Igarashi A, Potter RL, Grotendorst GR. Connective Tissue Growth Factor: a cysteine-rich mitogen secreted by human vascular endothelial cells is related to the SRC-induced immediate early gene product CEF-10. J Cell Biol 1991; 114: 1285-1294.

32. Murakami K, Matsura T, Sano M, et al. 4-[3,5Bis(trimetylsilyl)-benzamido] benzoic (TAC-101) inhibits intrahepatic spread of hepatocellular carcinoma. Cancer Res 1998; 58: 2234-2239.

33. Steffen CL, Ball-Mirth DK, Harding PA, Bhattacharyya N, Pillai S, Brigstock DR. Characterization of cellassociated and soluble forms of connective tissue growth factor (CTGF) produced by fibroblast cells in vitro. Growth Factors 1998; 15: 199-213.

34. Broekelmann TJ, Limper AH, Colby TV, McDonald JA. Transforming growth factor, $\beta 1$ is present at sites of extracellular matrix gene expression in human pulmonary fibrosis. Proc Natl Acad Sci USA 1991; 88: $6642-6646$.

35. Khalil N, $\mathrm{O}^{\prime}$ Connor RN, Unruh HW, et al. Increased production and immunohistochemical localization of transforming growth factor-beta in idiopathic pulmonary fibrosis. Am J Respir Cell Mol Biol 1991; 5: $155-$ 162. 